\title{
O VISCONDE DE BARBACENA E O QUÍMICO JOSÉ ÁLVARES MACIEL: ENCONTRO NA CIÊNCIA E DESENCONTRO NA POLÍTICA
}

\author{
Robson Jorge de Araújo e Carlos A. L. Filgueiras* \\ Departamento de Química, Universidade Federal de Minas Gerais, 31270-901 Belo Horizonte - MG, Brasil
}

Recebido em 27/11/2016; aceito em 04/01/2017; publicado na web em 14/02/2017

\begin{abstract}
THE VISCOUNT OF BARBACENA AND JOSÉ ÁLVARES MACIEL: CONNECTION IN SCIENCE AND DISCONNECTION IN POLITICS. These two men were former natural philosophy students from the University of Coimbra. Barbacena finished in 1775 and obtained a doctorate in 1776, whereas Maciel graduated in 1785 and then did scientific and industrial work in Portugal and England. The Viscount was a founder member of the Lisbon Academy of Sciences in 1779, and its secretary for 9 years. Both came to Brazil in 1788, when the Viscount was named Governor of Minas Gerais. Insofar as gold production was falling drastically, the Governorto-be saw in Maciel the right person to start a comprehensive survey of the mineral potential of his domain. Soon after their arrival their lives parted. Without leaving his scientific pursuits, Maciel became embroiled in the planned uprising known as Inconfidência Mineira and was arrested in late 1789. His promising scientific career was aborted at the age of 29 and he was sentenced to exile in Africa. His despondency contributed to an early death at 43 . The Viscount's fate is also gloomy, for in Brazil he is hardly remembered today for any devotion to science, but mainly as the harsh persecutor of patriots.
\end{abstract}

Keywords: Viscount of Barbacena; Álvares Maciel; eighteenth-century science; science and politics; Inconfidência.

\section{O VISCONDE DE BARBACENA, DA CIÊNCIA À POLÍTICA}

Luís António Furtado de Castro do Rio de Mendonça e Faro nasceu em Sacavém (Lisboa) em 1754 e morreu em Lisboa em 1830. Como filho do $5^{\circ}$ Visconde de Barbacena, ele herdou o título paterno e se tornou o $6^{\circ}$ Visconde daquela casa. A origem ancestral da família era a pequena Vila de Barbacena, no Alentejo, vizinha à cidade de Elvas e junto à fronteira espanhola. Barbacena foi habitada desde tempos remotos, pois ainda hoje se podem ver um monumento megalítico pré-histórico e uma ponte romana, além de um castelo medieval parcialmente arruinado.

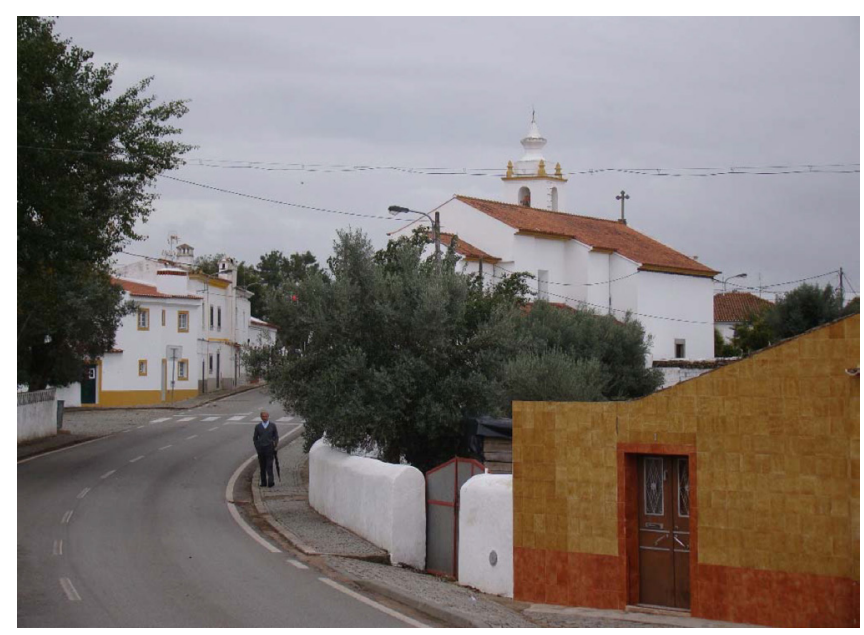

Figura 1. Aspecto da pequena vila alentejana de Barbacena, origem ancestral do Visconde de Barbacena. Foto de Carlos A. L. Filgueiras

O jovem Luís Antonio desde cedo demonstrou inteligência viva e por isso foi mandado pelo Marquês de Pombal, que desejava ter no reino aristocratas capazes, a estudar na Universidade de Coimbra, que acabava de ser reformada por iniciativa do próprio Pombal. Luís

*e-mail: calfilgueiras@gmail.com
Antonio graduou-se em Leis e Filosofia. Sua matrícula inicial foi realizada em 30/10/1772, em Direito Canônico, mas passou-se logo depois para a Faculdade de Leis. No ano seguinte matriculou-se no segundo ano filosófico, como mostra o Arquivo da Universidade. ${ }^{1}$ Formou-se em Leis em 07/07/1775 e doutorou-se em julho de 1776, sendo a primeira pessoa a se doutorar em Filosofia Natural em Coimbra. ${ }^{1}$ Enquanto seguia seus cursos, Luís Antonio chegou a reger a cadeira de história natural, quando finalizava o curso de Direito, por impedimento do Professor Domingos Vandelli. ${ }^{2}$ Após buscas incessantes no Arquivo da Universidade de Coimbra e na Academia das Ciências de Lisboa, da qual Barbacena viria a ser o primeiro secretário, nem sua tese ou sequer seu título foram encontrados. ${ }^{3}$

No livro que registra as Actas das Congregações da Faculdade de Filosofia (1772-1820), lê-se na Acta de 4 de março de 1776:

"E propondo-se uma petição de Luís Antonio Furtado de
Mendonça, estudante ordinário e bacharel formado nesta
Faculdade, que se acha em $5^{\circ}$ ano de graduação e pretendia
fazer as suas Conclusões Magnas, e na forma do estatuto, se
lhe deve assinar, nesta Congregação, a matéria para a disser-
tação que pedia se lhe assinasse, a que se lhe deferiu, assi-
nando-se-lhe a matéria seguinte: De incremento agriculture
quod obtinetur ex Historia Naturali, Physica Experimentali,
et Chymica (isto é, Sobre o incremento da agricultura que
se obtém da História Natural, da Física Experimental e da
Química)."4

Parece que, mesmo recebendo da congregação da faculdade a recomendação para um tema de tese, o jovem fidalgo não o tenha desenvolvido nem redigido a tese. Opina o Prof. Caio Boschi que o grau de doutor pode ter sido outorgado por ato administrativo, talvez por ordem do Marquês de Pombal. ${ }^{1}$

Pombal devia simpatizar com Luís Antonio, pois havia anteriormente escrito ao Bispo eleito de Coimbra e Reitor Reformador da Universidade, o brasileiro D. Francisco de Lemos de Faria Pereira Coutinho, um ofício de 15/12/1773, sobre o jovem Barbacena, que havia concluído o primeiro ano matemático, nos seguintes termos: 
"O louvor que V. Excia. me participa haver merecido Luís Antonio Furtado de Mendonça, na ocasião do exame público que fez de aritmética e geometria, se faz digno de que V. Excia. lho continue publicamente; e lhe faça compreender o grande contentamento que recebi com a notícia dos frutos de sua aplicação. Assim ficará ele mais animado a continuar com igual fervor e diligência; e dará estímulo aos outros mancebos seus condiscípulos e seus iguais, para aspirarem a merecer a distinção de semelhantes louvores." ${ }^{5}$

Depois do doutoramento de Barbacena em 1776, só em 26 de julho de 1778 haveria novos doutoramentos em filosofia em Coimbra. Nesse mesmo dia defenderam suas teses o brasileiro Joaquim Veloso de Miranda, natural do Inficionado, próximo a Mariana, e futuro notável botânico, ${ }^{6}$ e o português Teotônio José de Figueiredo Brandão. Lamentavelmente a tese de Veloso de Miranda, intitulada Theses ex Universa Philosophia (ou Teses de toda a Filosofia) se perdeu, ${ }^{1}$ mas a de Figueiredo Brandão foi localizada e fotografada por um dos atuais autores na Universidade de Coimbra. Ela consta de 12 páginas manuscritas e foi apresentada na data de 22 de junho de 1778. A tese trata de química, intitulando-se De Analogia Fluidum Electricum inter et Chymicorum Phlogisto, isto é, Da Analogia entre o Fluido Elétrico e o Flogisto dos Químicos. ${ }^{7}$ A tese é influenciada pelo químico inglês contemporâneo Joseph Priestley, que é citado, e discute um dos assuntos mais importantes nos debates químicos da época, a química do flogisto, defendida por Priestley, contra a qual surgia a nova química lavoisiana do oxigênio, que não é citada. Figueiredo Brandão procura um paralelo entre o que ele chama de fluido elétrico e o flogisto. A tese não desenvolve o tema de forma original, apenas discorre sobre a literatura corrente. Ao final da tese lê-se a assinatura do professor de química, Domingos Vandelli.

Pouco depois de deixar os bancos escolares, Barbacena veio juntar-se a D. João de Bragança, Duque de Lafões, e ao abade José

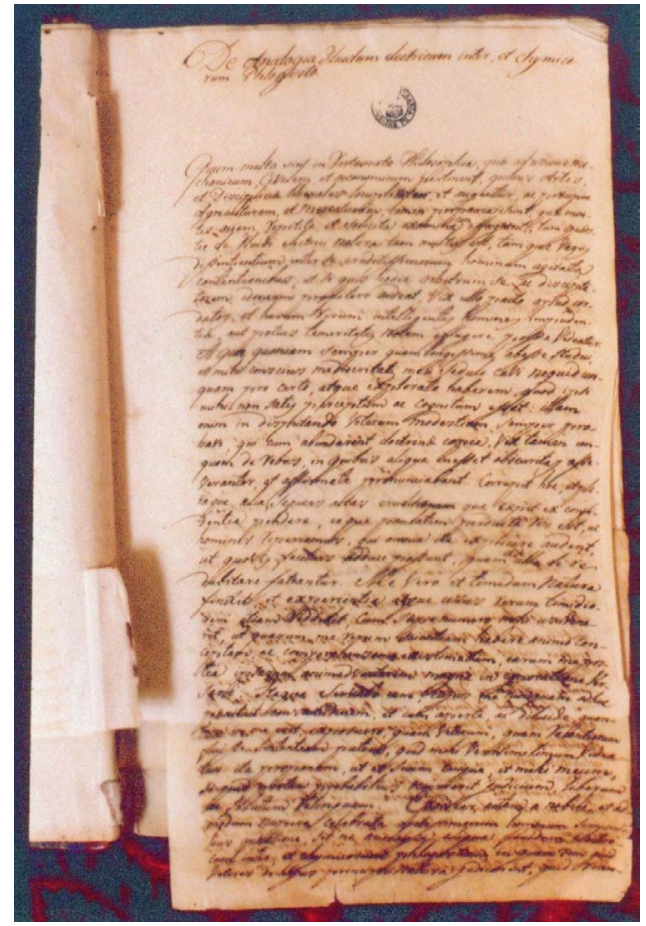

Figura 2. A tese de doutoramento em química de Teotônio José de Figueiredo Brandão, intitulada De Analogia Fluidum Electricum inter et Chymicorum Phlogisto, ou Da analogia entre o Fluido Elétrico e o Flogisto dos Químicos, defendida na Universidade de Coimbra em 1778. Foto de Carlos A. L. Filgueiras
Correia da Serra para tratarem da fundação da Academia das Ciências de Lisboa, mais tarde elevada pela Rainha D. Maria I a Academia Real das Ciências de Lisboa. O Duque de Lafões (1719-1806), tio da rainha, era o que se chamava na época um "estrangeirado", pois havia vivido 21 anos fora de Portugal, de 1757 a 1778, em diversos países da Europa, embora passando períodos mais longos em Viena. ${ }^{8}$ D. João era um homem cultíssimo, falava várias línguas e tinha uma grande preocupação em contribuir para o desenvolvimento intelectual e científico de Portugal.

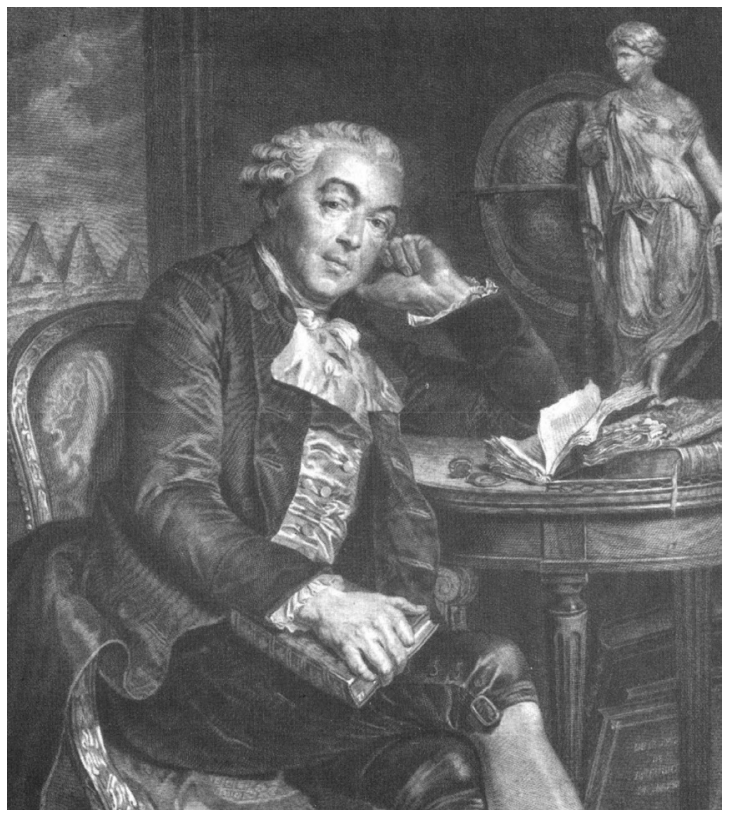

Figura 3. D. João de Bragança e Ligne, $2^{\circ}$ Duque de Lafões e primeiro Presidente da Academia das Ciências de Lisboa. Academia das Ciências de Lisboa

O Abade José Francisco Correia da Serra (1751-1823) era filho de um antigo contemporâneo do Duque de Lafões na Universidade de Coimbra. O pai do futuro abade formou-se em medicina, mas o duque não concluiu os estudos universitários. Em 1757 a família de Correia da Serra se mudou para a Itália, onde a mãe morreria em 1765, deixando grande prole. O pai retornou a Portugal em 1771, mas José Francisco só o faria em 1777. A família era de velha cepa cristã-nova e já se disse que José teria tomado ordens religiosas na Itália para proteger seus estudos científicos da Inquisição. ${ }^{9} \mathrm{O}$ certo é que ele não tinha vocação religiosa e em 1803 até teve um filho com uma jovem francesa. ${ }^{10}$

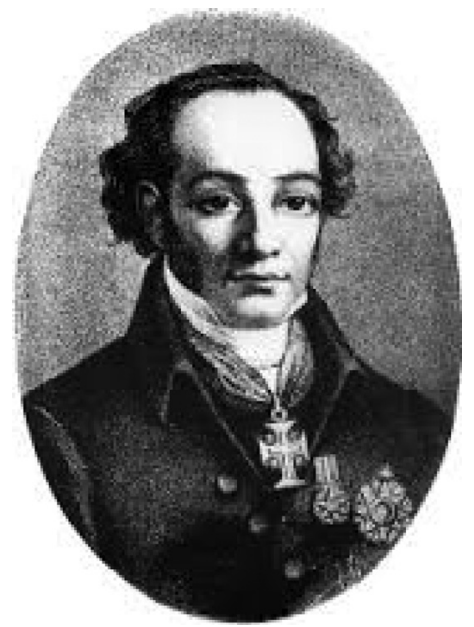

Figura 4. Abade José Correia da Serra. Academia das Ciências de Lisboa 
Então, ao final da década de 1770 encontram-se em Lisboa os três homens que irão fundar a Academia das Ciências: o duque, homem de vasta cultura e prestígio, membro da família real, o visconde, que seria uma espécie de executivo da academia, e o abade, aquele que efetivamente cuidava das ciências, por ser um devotado naturalista. O abade mudou-se para o Palácio do Grilo, residência do duque, e lá fizeram planos para fundar a nova academia. Para tal foi valiosa a contribuição do Professor Domingos Vandelli, o notável naturalista e químico de Coimbra. A Academia das Ciências conserva uma enorme coleção de cartas de Barbacena e do abade a Vandelli, dadas pelo filho deste, Alexandre Vandelli, em que se podem ler com detalhes todos os passos para a instalação e o funcionamento da Academia. ${ }^{11}$ A esmagadora maioria dessas cartas é de Barbacena, mas também há algumas escritas pelo Abade a Vandelli. Numa das primeiras cartas, de 18 de dezembro de 1779, assim diz Barbacena:

"Sr. Dr. Vandelli - Tenho o gosto de dizer a V. Sa. que tudo o que pretendíamos para a Academia está conseguido. A Rainha aprovou o nosso projeto por um aviso da secretaria de estado, o qual se nos entregou já, e nos dá casas no Palácio das Necessidades (nota dos autores: atual sede do Ministério dos Negócios Estrangeiros de Portugal), com que estamos contentes. Agora cuidaremos em principiar, e bem sentimos que V. Sa. não possa estar presente. Amanhã nos ajuntaremos provavelmente na casa do Duque para prepararmos e resolvermos particularmente os primeiros negócios, que depois hão de ser encaminhados a uma Assembleia particular de todos os sócios atuais..."12

A Rainha de fato aprovou o plano dos estatutos, dando à Academia seu diploma de fundação no dia 24 de dezembro de 1779 . Ela, todavia, começou a funcionar no dia 16 de janeiro de $1780 .{ }^{13}$ Em 4 de julho desse ano o orador oficial da Academia, Padre Teodoro de Almeida, autor e divulgador de textos científicos, sobretudo de física, em que sobressaem os dez volumes de sua Recreação Filosófica, ou Diálogo sobre a Filosofia Natural, pronunciou seu discurso inaugural. ${ }^{13,14}$

Na hierarquia da Academia, o Duque de Lafões permaneceu como presidente durante toda a sua vida, e o Visconde de Barbacena ficou como Secretário de 1779 até 1788 , quando foi nomeado Governador de Minas Gerais. O Abade Correia da Serra sucedeu a Barbacena como Secretário da Academia, mas é a ele que se devem os estatutos da mesma, e muitas iniciativas que asseguraram sua sobrevivência e prosperidade, justificando a divisa que ela ostenta desde sua fundação: nisi utile est quod facimus, stulta est gloria (se o que fazemos não é útil, tola é a glória).

Em 19 de fevereiro de 1780 escrevia Barbacena a Vandelli, numa demonstração de como o tinha em alta conta como seu orientador, e de como se sentia ainda sem autonomia científica:

\begin{abstract}
"Ainda não escolhi assunto para a minha primeira memória que hei de ler na Academia, a qual deve ser tal que não leve muito tempo a fazer: tem-me lembrado uma análise das águas de Lisboa, ou outro ponto semelhante, pelo que desejava que V. Sa. me mandasse algumas luzes a este respeito, e me inculcasse os melhores livros para o fazer; também me tinha lembrado a análise da atmosfera de Lisboa." ${ }^{15}$
\end{abstract}

Esta carta de Barbacena o mostra como homem de seu século, que acha importante conhecer a ciência e até fazer algum trabalho científico, mas como aristocrata, desejava que o trabalho não fosse tão exaustivo. Há um contraste enorme entre esta postura de Barbacena, de estudar por livros e não pela natureza, com aquela do médico brasileiro José Pinto de Azeredo, seu contemporâneo, que em 1790

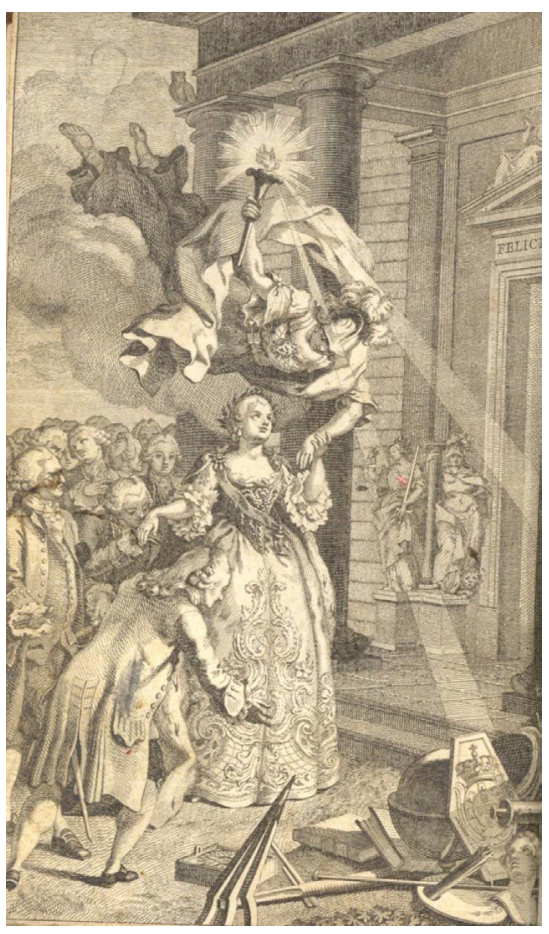

Figura 5. Alegoria às Ciências e a sua proteção pela Rainha D. Maria I, publicada no primeiro número do Jornal Enciclopédico, de 1779

publicou um longo trabalho experimental de 30 páginas sobre seus experimentos a respeito da atmosfera do Rio de Janeiro em 9 locais distintos da cidade, medindo os teores de oxigênio e de gás carbônico, para determinar a "bondade" do ar, que seria tanto maior quanto maior fosse o teor do primeiro e menor o do segundo. ${ }^{16,17,18}$

Para o Abade Correia da Serra, contudo, Barbacena era "moço de grandes esperanças", que fazia "tanta honra à escola donde saiu como à Academia em que entra". ${ }^{19}$

Como secretário da Academia, a atuação de Barbacena parece ter sido bastante eficaz, merecendo portanto os elogios de Correia da Serra. Este escreve a Vandelli em 6/5/1780, relatando os progressos da nova associação na criação de seu acervo, para o quê muito contribuía Barbacena:

“Sr. Dr. Domingos Vandelli - Cá o espero com todo o alvoroço para ver com os seus olhos a neonata Academia ... Os livros que o Sr. Dr. Vandelli mandou já têm achado companheiros, e entre grandes e pequenos estamos perto de duzentos volumes ... A coleção de cousas naturais está alguma cousa adiantada ..." 20

Todos esses pormenores sobre Barbacena são dados aqui para mostrar o tipo de formação e meio em que ele atuou antes de ser nomeado Governador de Minas Gerais em 1788, cargo em que permaneceu até 1797 .

Tudo leva a crer que, apesar de ter grande interesse pela ciência, sua posição como membro da aristocracia talvez o inibisse para a realização de trabalhos experimentais, isto é, manuais, como parecem mostrar os dois casos citados, no primeiro ao receber da congregação da Faculdade de Filosofia de Coimbra um tema para tese, que aparentemente nunca se materializou, e mais tarde o pedido feito a Vandelli que o orientasse a fazer um trabalho para ser lido na Academia, que tampouco se realizou. Este segundo caso é eloquente em demonstrar a dependência científica de Barbacena, que quase implora a Vandelli que o ajude.

É difícil ver no Brasil uma descrição de Barbacena em que ele não seja mostrado pejorativamente, em virtude de seu envolvimento 
na repressão à Inconfidência Mineira. Todavia, caso fossem outras as circunstâncias e menor a intransigência do ministro Martinho de Melo e Castro, que sempre acreditou que a diminuição nas remessas de ouro para o reino se devia à sonegação, e não à exaustão das minas, Barbacena talvez pudesse ter sido uma mola propulsora no sentido de desenvolver sucedâneos minerais importantes a serem explorados no território que lhe foi confiado como governante.

As instruções dadas a Barbacena ao partir para assumir seu novo posto em Vila Rica constavam de 123 parágrafos e mais de 20 anexos. ${ }^{21}$ Seu autor, o Ministro Martinho de Melo e Castro, Secretário da Marinha e Ultramar, admitia que "é certo que uma grande parte dos abusos e prevaricações que têm pervertido a ordem e regularidade do governo de Minas tem a sua origem nas violências e injustiças que os ministros praticam nas correições e outras diligências a que vão no interior da capitania..." Contudo, Melo e Castro não aceitava "as afetadas e sinistras asseverações e declamações daqueles habitantes em quererem persuadir que as minas se achavam exaustas ou cansadas." Ao contrário, para ele, a diminuição da produção aurífera "procede de uma grande relaxação nos que têm a seu cargo a inviolável observância das leis". ${ }^{22}$ Esta última observação atinge diretamente os vários advogados formados em Coimbra que vieram a participar da Inconfidência. As instruções de Melo e Castro também invectivavam contra os altos salários pagos aos sacerdotes, muitos dos quais também se tornaram conspiradores, e propunha uma diminuição para um quarto de seus valores. ${ }^{21}$ Pode-se imaginar, apenas por esses poucos exemplos, a rígida intransigência do ministro, em determinações que competia ao jovem governador apenas implementar, e não interpretar. Barbacena se encontrava então num dilema pessoal. Se ele tivesse tido mais liberdade de ação, e este é apenas um exercício mental, talvez pudesse ter passado à história como o homem que poderia ter iniciado uma atividade científica pioneira em seu governo, contando para isso com a colaboração competente do cientista José Álvares Maciel. Lamentavelmente não foi isso o que sucedeu, e tanto Maciel como Barbacena veriam frustrar-se quaisquer planos que pudessem ter imaginado nesse sentido. Não só isso, mas os dois acabaram passando à história como antagonistas num profundo drama humano, em que um veio a tornar-se o perseguidor e o outro sua vítima.

Barbacena, de 34 anos, parte para o Brasil com a família em 11/2/1788. O jovem cientista brasileiro de 28 anos, José Álvares Maciel, embarcou para sua terra no início de março daquele ano, chegando ao Rio ao final de junho. No final desse mês eles tiveram um rápido encontro, ainda no Rio, e o Visconde seguiu para Vila Rica em 11 de julho, para tomar posse de seu cargo. A família do Governador permaneceu no Rio, pois a Viscondessa não estava bem de saúde. ${ }^{23}$

Como diz Tarquínio J. B. de Oliveira, para Barbacena o encontro com Maciel havia sido "providencial, pois lutara inutilmente na Corte para obter um mineralogista competente que o assessorasse no futuro governo. Maciel caiu-lhe do céu." ${ }^{23}$

\section{JOSÉ ÁLVARES MACIEL, O QUÍMICO INCONFIDENTE}

José Álvares Maciel nasceu em 1760, em Vila Rica, filho de pai homônimo, e de Juliana Francisca de Oliveira. A família tinha posses e bastante prestígio na região mineira. Interessada na educação dos filhos, manda-os a estudos para a Universidade de Coimbra. Francisco e Teotônio, irmãos mais velhos, seguem para Coimbra junto com José, e os três se matriculam na universidade em 1782, os dois primeiros em Leis e o último em Filosofia. ${ }^{24}$ José concluiria o curso de Filosofia Natural em 16 de julho de 1785, tendo sido aprovado Nemine Discrepante, isto é, por unanimidade. Seu diploma encontra-se hoje no Museu da Inconfidência, em Ouro Preto, e está mostrado na Figura 6.

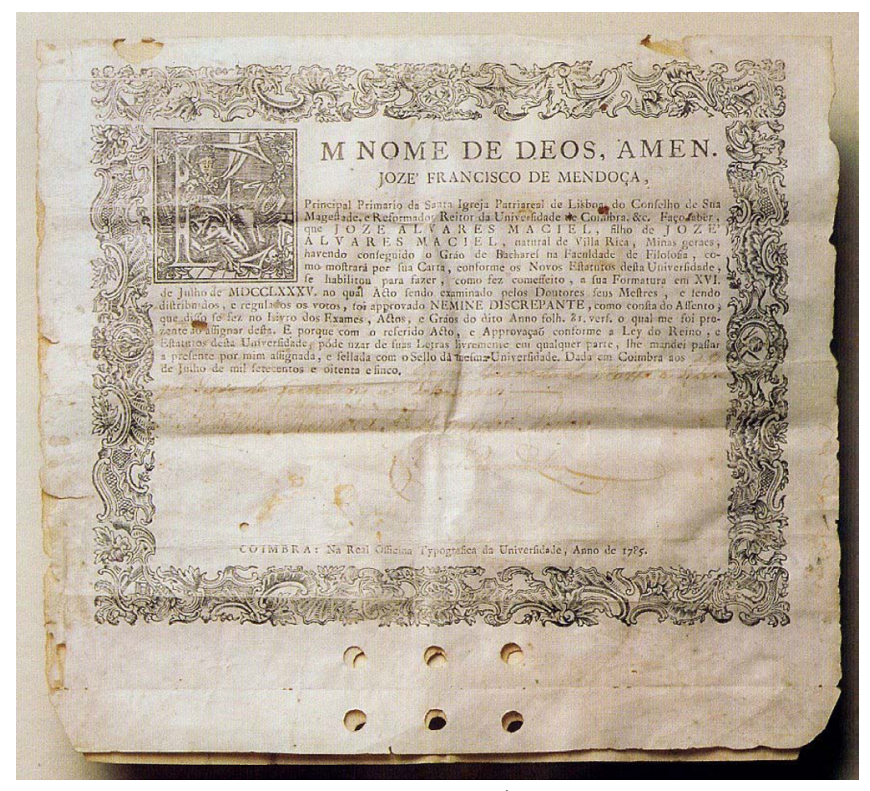

Figura 6. Diploma de graduação de José Álvares Maciel na Universidade de Coimbra, com a data de 16 de julho de 1785. Museu da Inconfidência, Ouro Preto

Na universidade, Maciel estudou Matemática, Filosofia Racional e Moral, História Natural (Botânica, Zoologia e Mineralogia), Geometria, Física Experimental e Química.

Maciel foi aluno de química do professor Domingos Vandelli, um expatriado italiano que teve uma longa e distinta carreira em Portugal, tanto na química como na história natural. Vandelli tivera o cuidado de "fazer bem conhecer aos seus discípulos os diferentes produtos, e substâncias do reino mineral; costumando-lhes os olhos a distingui-los pelos sinais exteriores, que os caracterizam; mostrando-lhes as partículas deles, que se guardarão no Museu, ou Gabinete de História Natural". Também se preocupava em dar-lhes, ao mesmo tempo, "uma ideia geral do modo com que estas substâncias se acham arrumadas, e em camadas nas entranhas da Terra; dos sinais que anunciam a presença das minas; e de tudo o mais que pertence $\grave{a}$ História desta parte da Ciência Natural. Em segundo lugar, mostrará as propriedades observadas em todas as referidas substâncias; recolhendo todos os fatos que forem, ou puderem ser de alguma utilidade no uso das Artes." 25

Vandelli exerceu grande liderança como professor, pois infundiu enorme entusiasmo em seus alunos ao realizar seus projetos escolares. Depois que os irmãos Montgolfier começaram a fazer voar balões de ar quente na França em 1783, Vandelli convenceu seus estudantes a fazer o mesmo em Coimbra. Eles começaram a construir e lançar balões de ar quente, que logo seriam seguidos por balões de hidrogênio. Desse modo a Gazeta de Lisboa nos conta que quatro dos alunos de Vandelli, entre eles José Álvares Maciel e seu conterrâneo mais jovem Vicente Coelho de Seabra, construíram em 1784 uma "máquina aerostática" que subiu ao ar em duas ocasiões, nos dias 25 e 27 de junho daquele ano. ${ }^{26}$ A máquina era um balão de ar quente com 30 palmos $(6,6 \mathrm{~m})$ de diâmetro e 45 palmos $(9,9$ m) de altura. A Gazeta informava também que "esta máquina se achava prestes no Laboratório de Química da Universidade para ser lançada aos ares a 15 de junho", mas Vandelli pediu aos estudantes para esperar alguns dias para que o Reitor pudesse estar presente ao lançamento. No ano seguinte, a Gazeta de Lisboa noticiou que os discípulos de Vandelli estavam lançando tanto balões de ar quente como aqueles com o "gás proximamente descoberto pelo célebre Priestley, cujo método tende a fazer passar os vapores da água e do álcool para um tubo de metal em brasa e cheio de pequenas tachas 
de ferro". ${ }^{27} \mathrm{O}$ entusiasmo dos estudantes pelo "gás de Priestley" era tamanho que foi um milagre a universidade não ter sido reduzida a cinzas. No aniversário do consorte da Rainha D. Maria I, o Rei D. Pedro III, eles empreenderam uma celebração especial. De acordo com a Gazeta, "além da iluminação de costume se formou no terreiro da Universidade, defronte do palácio, uma gruta em que estava uma fonte perene de fogo, que ardeu das sete até às duas horas: eram mais de 150 chamas contínuas, todas com diversas direções". ${ }^{28}$ De fato a quantidade de hidrogênio deve ter sido enorme, e foi por verdadeira sorte que nenhum acidente sério ocorreu.

Aluno excepcional, Maciel impressionou seu mestre Domingos Vandelli, que o convidou a realizar pesquisas mineralógicas na Serra da Estrela, vizinha a Coimbra. Vandelli cita-o como descobridor de ricas jazidas de arsênio nessa região, além de autor de várias classificações de rochas. ${ }^{29}$

Após sua formatura e estágio de prospecção mineralógica na Serra da Estrela, Maciel foi para a Inglaterra, onde viveu por 18 meses na cidade de Birmingham. Tempos depois, já no Brasil, seria preso em Vila Rica como implicado na Inconfidência Mineira e remetido para o Rio de Janeiro. Na primeira inquirição a que foi submetido na Fortaleza de Villegagnon, em 26 de novembro de 1789, foi-lhe perguntado se na Inglaterra ele havia tratado do levante pela independência das Minas Gerais, com auxílio dos ingleses. Sua resposta, bastante interessante como forma de desconversar, foi de que ele se havia dirigido à Inglaterra para conhecer suas manufaturas e desenvolvimento industrial. De fato, a cidade de Birmingham era um dos centros da Revolução Industrial que nascia. Além disso, em Birmingham vivia o mais eminente químico inglês da época, Joseph Priestley, amigo do cientista português expatriado João Jacinto de Magalhães. ${ }^{30}$ Aliás, foi Magalhães quem apresentara Priestley a Lavoisier em Paris. ${ }^{31}$ Numa das respostas de Maciel a seus inquiridores, registrada nos Autos de Devassa da Inconfidência Mineira, lê-se: "respondeu que se não tratou o negócio (da sublevação) com mais miudeza alguma, do que tem declarado, mas sim se falou em manufaturas, mas ele, respondente, se não encarregou delas, nem podia se encarregar delas, porque em um ano e meio que esteve na Inglaterra, não podia compreender coisa de consideração, mais que alguma curiosidade, que não fora mandado por pessoa alguma à Inglaterra, aonde fora para melhor se instruir na química, tendo para isso a módica assistência que lhe fazia seu pai, de dez mil réis por mês, e que naquele reino não ouvira falar nunca em pretensão de levante desta América, a única coisa que ouviu, que respeitasse a América foi dar-se a novidade em uma gazeta de Oxford, que tinha falecido o Ilmo. e Exmo. Vice-Rei do Brasil, Luís de Vasconcelos de Sousa". ${ }^{32}$ É claro que esta última notícia era falsa.

Muitos pesquisadores já tentaram em vão obter mais dados sobre esse período da vida de Álvares Maciel. Na realidade, só se sabe isso que ele declarou a seus inquiridores, isto é, que viveu um ano e meio na Inglaterra, entre fins de 1786 e princípios de 1788, tendo ido por iniciativa própria, custeado por seu pai. Como ele próprio disse, sua ida àquele país tivera por objetivo "melhor se instruir na química". É claro que Birmingham era um excelente local para esse propósito, dada a presença de Priestley na cidade. A descoberta no futuro de alguma coisa a este respeito lançaria uma luz importante sobre o assunto.

Frei Raimundo de Penaforte, que assistiu aos inconfidentes na prisão e esteve presente à execução de Tiradentes, escreveu alguns anos depois, a respeito de José Álvares Maciel: "era de uma rara instrução. Depois de ter frequentado a Universidade de Coimbra e de ter recebido o grau de bacharel em ciências naturais, viajou pela Europa imitando Pedro, o Grande, no encoberto de seus intentos - que eram visitar todas as fábricas e oficinas, o que conseguiu, pois alcançou o segredo de muitas; e os poria em execução, se essa abrasadora chama da liberdade que se prendeu em seu coração, ao passar pela fornalha da oficina da franco-maçonaria, não lhe devorasse as entranhas. Voltou à sua pátria; e a identidade de opinião e de costume, e parentesco, o precipitaram". ${ }^{33}$

Após o longo estágio inglês Maciel retornou a Lisboa e de lá regressou ao Brasil, chegando ao Rio de Janeiro ao final de junho de 1788. Foi em sua curta estada no Rio, antes de prosseguir para sua Vila Rica natal que ele travou conhecimento com Joaquim José da Silva Xavier, o Tiradentes.

Supõe-se que na Inglaterra as ideias da emancipação política da sua pátria o possam ter movido mais do que os seus estudos, ${ }^{34}$ e que enquanto José Joaquim Maia, estudante brasileiro de Medicina na Universidade de Montpellier, conferenciava sobre este assunto com Thomas Jefferson, embaixador dos Estados Unidos na França, ${ }^{35}$ ele, ainda na Inglaterra, sondava a disposição dos ingleses a nosso respeito. Esta suposição, contudo, não teve de sua parte qualquer revelação, pois ele sempre se manteve firme em dizer que só o movera na Inglaterra a disposição de estudar química e as manufaturas inglesas..$^{32}$ De acordo com o historiador Tarquínio J. B. de Oliveira, José Joaquim da Maia e Barbalho doutorou-se em Medicina em Montpellier em 10/5/1787 com a tese Febre Erisipelatosa. Ele trocou cartas com Thomas Jefferson em 1786 e 1787. Maia havia iniciado seus estudos em Coimbra e depois se transferira para Montpellier, onde também estudaram vários outros brasileiros na época. Ele provavelmente nascera no Rio de Janeiro em 1752, e em Coimbra fora contemporâneo de Maciel. ${ }^{36}$ Outro inconfidente, Domingos Vidal de Barbosa, que fora inicialmente aluno de Medicina em Montpellier e mais tarde em Bordeaux, relatou como testemunha em 16/6/1789 na Cadeia de Vila Rica, que Maia havia metido na cabeça que haveria de ser o libertador de sua terra. ${ }^{36}$ Jefferson não fez grande caso de Maia, pois não convinha aos Estados Unidos hostilizar Portugal naquele momento, em favor de um movimento libertário brasileiro altamente temerário. No relatório enviado por Jefferson ao Secretário de Estado dos Estados Unidos, John Jay, diz ele a certa altura, a respeito de sua entrevista com Maia:

\begin{abstract}
"Durante toda a nossa entrevista tive o cuidado de fazer ver ao meu interlocutor que eu não tinha instruções, nem autoridade, para dizer uma palavra a quem quer que fosse sobre este assunto, e que somente podia comunicar-lhe minhas ideias como simples particular. Disse-lhe que na minha opinião não estávamos presentemente em estado nacional de nos intrometer em uma guerra; que desejávamos particularmente cultivar a amizade de Portugal, com quem entretínhamos um comércio vantajoso. Todavia uma revolução bem sucedida no Brasil não podia deixar de interessar-nos; que as perspectivas do lucro poderiam atrair certo número de indivíduos em seu auxílio, assim como, guiados por motivos mais puros, oficiais nossos, entre os quais não faltavam militares excelentes; que os nossos concidadãos, tendo a faculdade de deixar individualmente o seu próprio país sem consentimento do governo, têm também a liberdade de ir para qualquer outra terra." ${ }^{37}$
\end{abstract}

O encontro entre Maia e Jefferson se deu em Nîmes, perto de Montpellier, em 21/3/1787, durante a estada do americano no sul da França. Na segunda carta do maçon Maia ao igualmente maçon Jefferson, assinada com o pseudônimo Vendek, assim se expressa Maia: “...é a vossa nação que julgamos mais própria a ajudar-nos, não somente porque foi quem nos deu o exemplo, mas também porque a natureza fez-nos habitantes do mesmo continente e, por conseguinte, de alguma sorte compatriotas; pela nossa parte estamos prontos a dar todo o dinheiro que for necessário e a manifestar a todo tempo a nossa gratidão para com os nossos benfeitores". ${ }^{37-39}$ Depois de seu doutoramento em Montpellier, Maia passou alguns meses em Bordeaux, já 
muito enfermo de tuberculose. Ao final de 1787 chegava a Portugal, mas faleceu em fevereiro de 1788. Mais tarde Maciel informaria a Tiradentes, em julho de 1788, que os comerciantes franceses de Bordeaux enviariam três navios ao Rio de Janeiro, com suprimentos para a revolta, caso ela ocorresse. Tarquínio J. B. de Oliveira sugere que isso possivelmente se devesse a alguma intercessão favorável nesse sentido por parte de Jefferson. ${ }^{40}$

Após o desbaratamento da Inconfidência, e antes de ser levado preso para o Rio de Janeiro, Maciel foi alvo de uma inquirição (a segunda) na Casa do Contrato de Vila Rica, em 8 de outubro de 1789, quando ocorreu o seguinte diálogo com as autoridades: "e perguntado mais se ele, respondente, tinha a História da América Inglesa e as Leis Constitutivas dos Estados Unidos, e se emprestou a alguém aqueles livros, respondeu que tinha comprado por dois xelins a História da América Inglesa, em Birmingham. E cuidando que tinha feito uma grande compra, por ser em um leilão, se achou depois com uns poucos de folhetos - e tudo mutilado. Cujos livros se acham ainda encaixotados no Rio de Janeiro, em poder de Francisco José Freire, negociante naquela praça". ${ }^{41}$

José Álvares Maciel, além de filho do capitão-mor de Vila Rica, era também cunhado do tenente-coronel Francisco de Paula Freire de Andrade, comandante dos dragões e filho bastardo do Governador Gomes Freire de Andrade, sobrinho este do famoso Conde de Bobadela. Francisco de Paula Freire de Andrade foi um dos líderes da Inconfidência. Maciel era considerado peça-chave na conspiração, por ser químico, e viria a ser encarregado de fazer a pólvora necessária ao levante.

Na quarta inquirição a que foi submetido o alferes Joaquim José da Silva Xavier na Fortaleza da Ilha das Cobras, no Rio de Janeiro, em 18 de janeiro de 1790, disse Tiradentes:

“... que a primeira pessoa a quem falou, propondo-lhe o intento da sublevação e motim, foi nesta cidade a José Álvares Maciel, filho do capitão-mor da Vila Rica, o qual aprovou o projeto da premeditada sublevação e motim"... "porque tendo ele chegado da Inglaterra, e indo ele respondente visitá-lo em razão de ser cunhado de seu tenente-coronel, falaram sobre os conhecimentos que o dito José Álvares Maciel tinha adquirido a respeito de manufaturas e mineralogia, dizendo que os nacionais desta América não sabiam os tesouros que tinham, e que podiam aqui ter tudo se soubessem fabricar ... José Álvares Maciel disse que, pelas nações estrangeiras por onde tinha andado ouvira falar com admiração de não terem seguido o exemplo da América inglesa". ${ }^{42}$

O entusiasmo de Álvares Maciel pela sublevação deve ter sido bem grande. Na inquirição de testemunhas de 15 de maio de 1789 na Fortaleza da Ilha das Cobras, a primeira testemunha, o delator Joaquim Silvério dos Reis declarou: "José Álvares Maciel, filho do Capitão-mor de Vila Rica do mesmo nome e cunhado do Ten. Cel. da Cavalaria paga da Capitania de Minas Gerais, pela inteligência que tem de história natural e instrução sobre diferentes matérias, fazia a pólvora - em cuja diligência andava já e que, entrando seu pai, dito Capitão-mor, na confiança de que ele tomava parte nesta sedição e motim, lhe dissera: - 'Ó meu filho: não sejas infiel à nossa Soberana, porque se o fores, ser-me-á mais fácil cortar-te a cabeça do que ver-te metido em semelhantes perturbações', ao que o dito José Álvares Maciel filho respondera: que seu pai estava caduco". ${ }^{43}$

Voltando ao Brasil em meados de 1788, Maciel conhecera Tiradentes em julho, no Rio de Janeiro. Este ouviu do jovem doutor as ideias iluministas, ganhando de Maciel um livrinho contendo fundamentos da nova república americana e a história de sua autonomia. Este livrinho é o Recueil des Loyx constitutives des Colonies
Angloises Confédérées sous la Dénomination d'Etats-Unis de l'Amérique Septentrionale, de 1787, obra publicada na Suíça, em tradução francesa, mas sem conter a Constituição daquele país, como equivocadamente se afirma com frequência, pois é anterior a este documento. Outros conjurados também conheciam essa obra: o cônego Luís Vieira da Silva, por exemplo, falava sempre naquela independência e na organização nacional do país livre; ele e os conjurados mais cultos, como Cláudio Manuel da Costa, Tomás Antônio Gonzaga, Alvarenga Peixoto e mesmo outros menos informados. ${ }^{44}$

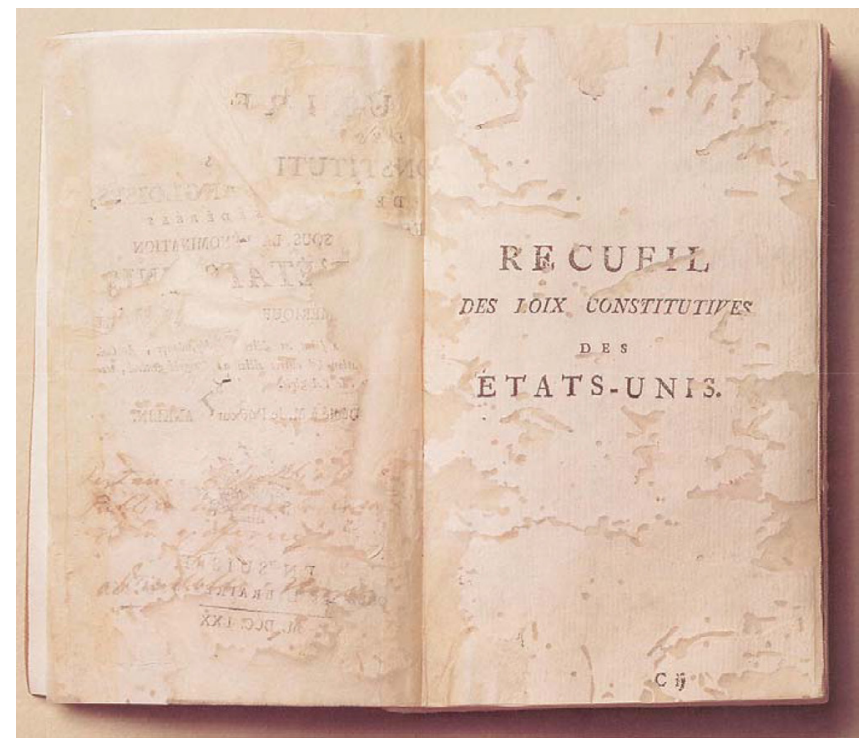

Figura 7. O livro Récueil des Loix Constitutives des Colonies Angloises, Confédérées sous la Dénomination D'Etats-Unis de l'Amérique Septentrionale, importante raridade bibliográfica, presenteado por José Álvares Maciel a Tiradentes, ao chegar da Europa. Em 1860 o exemplar foi dado por Alexandre José de Mello Moraes, Diretor da Biblioteca Nacional, à Biblioteca Pública de Santa Catarina. Em 1984, durante o governo de Tancredo Neves em Minas, o Governador catarinense Espiridião Amin veio a Ouro Preto na cerimônia de 21 de abril e devolveu a relíquia a Minas Gerais, onde se encontra no Museu da Inconfidência

Ao chegar ao Brasil, Maciel logo formou uma ligação com Barbacena. Conforme relata o historiador Tarquínio J. B. de Oliveira, "no dia 22-09, o Visconde de Barbacena achava-se no Registro do Paraibuna, para receber a esposa e os filhos que deixara no Rio com o tio Vice-Rei. Havia feito preparar previamente 8 pousos entre o Paraibuna e Cachoeira do Campo, para maior conforto da família na viagem. José Álvares Maciel acompanhou-o desde o Rio de Janeiro." ${ }^{45}$

É interessante um apontamento feito por Sérgio Paulo Rouanet em que diz: "certa vez o Visconde de Barbacena (governador da Capitania e amigo de Maciel) hospedou Maciel em sua casa e por duas vezes entrou no quarto do hóspede, sem aviso prévio: das duas vezes, o imprudente estava mergulhado na leitura das leis americanas". ${ }^{46}$ Esta informação de Rouanet enfatizando a imprudência de Maciel, certamente provém de um trecho do depoimento do delator Joaquim Silvério dos Reis prestado na Fortaleza da Ilha das Cobras, no Rio de Janeiro, em 18/5/1789: “... sendo chamado pelo sobredito General ... lhe disse que as provas da verdade da sublevação e motim intentado do qual lhe tinha dado parte, tinham crescido pelas observações que desde então tinha feito a esse respeito: primeiro, porque, tendo-se introduzido em sua casa José Álvares Maciel, filho do Capitão-mor do mesmo nome, a título de boa instrução, indo o dito general duas vezes a seu quarto, inesperadamente, sempre o achou lendo a história do levantamento da América Inglesa; e é verdade que, na primeira ocasião que a este respeito falou ao dito Ilmo. e Exmo. General, viu 
que o dito José Álvares Maciel andou sempre observando se podia perceber o que ele tratava com o dito Ilmo. e Exmo. General, tanto assim que, na segunda vez houve da parte do dito Ilmo. e Exmo. General a cautela de fazer que ele, por diferente e pretextando motivo, estivesse fora de casa." ${ }^{47}$

Existem vários testemunhos da proximidade entre Maciel e o Governador Barbacena. Numa carta anônima escrita de São João del Rei para o Porto, e conservada na Biblioteca Municipal desta última cidade, ao relatar a prisão do ten.-cel. Freire de Andrade em outubro de 1789, lê-se: "no mesmo dia foi recolhido à prisão seu cunhado José Álvares Maciel, cuja prisão admira - pois é sujeito muito próximo do palácio do General e mestre de seus meninos, tendo vindo com ele de Lisboa." 48

Em carta de Barbacena de 06/5/1789 a seu tio, o Vice-Rei D. Luís de Vasconcelos e Sousa, assim se expressa o Governador: "José Álvares Maciel, que se acha comigo nesta residência, tem dobrado de ardor e diligência. Desde certo tempo, na indagação de minas (especialmente de cobre e de ferro, que ensaia repetidas vezes, por sua curiosidade e até com despesa própria), e anda com grande desejo de salitre, de forma que, se as minhas ocupações me não tivessem afastado deste gênero de aplicação, teria ele já fundido em grande e adiantado muito mais os seus conhecimentos nesta parte." 49

Maciel se havia tornado tão íntimo do Governador, que uma vez chegados a Minas, o jovem cientista residiu por vários meses no palácio de Barbacena, na Vila de Cachoeira do Campo. ${ }^{50}$ Esta longa intimidade entre os dois fez com que Maciel, que era até mesmo preceptor dos filhos de Barbacena, como mostrado acima, fosse dos últimos inconfidentes a ser preso. Ao que parece, Barbacena relutou e só o mandou prender quando as evidências do envolvimento de Maciel na sedição se tornaram muito fortes.

Tiradentes havia sido preso no Rio em 10 de maio de $1789,{ }^{51} \mathrm{e}$ um homem importante como o Dr. Cláudio Manuel da Costa havia sido preso em 25 de junho e cometido suicídio na prisão em 4 de julho. ${ }^{52}$ Maciel só foi preso bem depois, como relatado a seguir. $\mathrm{O}$ Governador teve que fazer uma escolha e permaneceu fiel à coroa a que servia como vassalo, rompendo a amizade com aquele que para ele se havia tornado um traidor. Pode-se presumir até certo ponto um drama pessoal nessa escolha de Barbacena.

De acordo com nota apensa aos Autos de Devassa da Inconfidência Mineira, de autoria do historiador Tarquínio J. B. de Oliveira, a ordem de prisão do tenente-coronel Freire de Andrade e de José Álvares Maciel data de 4 de setembro de 1789, tendo sido ela efetivada em 4 de outubro, e a remoção dos réus para o Rio de Janeiro ocorrido em 12 de outubro. ${ }^{53}$

José Álvares Maciel envolveu-se mais intensamente na Inconfidência justamente quando estava começando a trabalhar em pesquisas mineralógicas. De fato, em nota de Tarquínio J. B. de Oliveira aos Autos de Devassa, lê-se que uma portaria da Real Fazenda, de 15 de julho de 1789 manda que se entregue a Maciel material destinado a seus trabalhos científicos, quando vários de seus futuros companheiros de infortúnio já haviam sido presos. Esta ordem da Real Fazenda data de menos de dois meses antes de sua ordem de prisão. Barbacena sempre esteve interessado em sua possível colaboração científica, ${ }^{54}$ e até pouco antes de ser preso Maciel residia no palácio do Governador, em Cachoeira do Campo. Ao ser preso, nada se lhe confiscou, tendo ele sido declarado filius familias, isto é, dependente de sua família, sem possuir quaisquer bens. ${ }^{55}$

No período entre sua chegada a Vila Rica em 1788 e sua prisão, mais de um ano depois, Maciel chegou a desenvolver vários trabalhos científicos, em consonância com os propósitos de Barbacena para o desenvolvimento da Capitania, como homem familiarizado com a ciência e suas aplicações. O escritor português Padre Manuel Ruela Pombo descobriu e publicou no início do século $\mathrm{XX}$ vários escritos relativos a Maciel durante seu período angolano. Francisco Antonio Lopes transcreveu muitos desses papeis sobre Maciel, dados a conhecer por Ruela Pombo, que mostram suas atividades como pesquisador em Vila Rica e depois no exílio de Angola. Assim, numa carta do Governador de Angola, D. Miguel Antonio de Melo, ao Ministro do Ultramar, D. Rodrigo de Souza Coutinho, datada de Luanda, em 19 de setembro de 1799 , pode-se ler:

"O digníssimo Governador atual da Capitania de Minas Gerais (Barbacena havia deixado o cargo em 1797, substituído por D. Bernardo de Lorena, ex-Governador de São Paulo) certamente terá dado a V. Excia. notícia das riquezas que ali existem, mas por que espero V. Excia. desculpe a liberdade que tomo de lhe participar o que sei, tenho a honra de dizer a V. Excia. que José Álvares Maciel me certificou ter descoberto em Vila Rica nas fraldas do Seramenha (sic) junto ao rio que ali passa no Distrito da Freguesia de Antonio Dias, vitríolo de cobre (sulfato de cobre), o qual corre dentre um banco de squisto (xisto), e nos tempos de seca costuma cristalizar-se em pequenas pirâmides. Que no mesmo sítio achou uma argila micácia semelhante à mica e de cor verde, que exposta ao fogo perde em breve espaço a cor, e se liquida como o vidro. Que no Morro das Lages há abundância de arsênico, de ouro pimenta (ouro-pigmento, ou sulfeto de arsênio) e de ferro, e na mina chamada do Contijo enxofre. E finalmente que desde a Cachoeira do Campo até São João do Morro Vermelho há um banco de pedras agregadas que têm uma braça (cerca de 2,2 metros) de largo, e outra de alto no qual descobriu grande riqueza de cobre puro. Estas notícias que para V. Excia. não serão novas me diminuem o descontentamento com que fico quando acerto de pegar na pena para informar a V. Excia. da pobreza e do estado de infância em que se acha este Reino." ${ }^{56}$

O Ministro D. Rodrigo de Souza Coutinho oficia a D. Bernardo de Lorena, Governador de Minas, nos seguintes termos:

"O Príncipe Regente N. S. manda remeter a V. Excia. a cópia inclusa do parágrafo de uma carta que me dirigiu o Governador de Angola, com data de 19 de setembro do ano próximo passado, para que V. Excia. informe do estado em que se acham as descobertas que fez nessa Capitania José Álvares Maciel, de que trata o mesmo parágrafo, e se elas têm tido seguimento." ${ }^{57}$

Kenneth Maxwell aponta algumas das aspirações dos conjurados da Inconfidência Mineira, em que os talentos de Maciel seriam muito úteis:

"Manufaturas seriam implantadas, estimulada a exploração de depósitos de minério de ferro. Seria criada uma fábrica de pólvora, libertados os escravos e mulatos nascidos no país, fundada uma Universidade em Vila Rica. As mulheres que gerassem determinado número de filhos receberiam um prêmio pago pelo Estado ... Seria instalado um parlamento em cada cidade, subordinado a um parlamento principal da capital. O desembargador Gonzaga governaria durante os primeiros três anos - depois disto haveria eleições anuais. Não seriam admitidas distinções ou restrições no vestuário e os ricos seriam forçados a usar produtos manufaturados 'localmente', entre outras ideias propostas". ${ }^{58}$

$\mathrm{Na}$ verdade, de acordo com um dos principais inconfidentes, a sede da projetada universidade não seria Vila Rica, e sim São João 
del Rei, como se pode ler na carta do Tenente-Coronel Domingos de Abreu Vieira, escrita na Cadeia de Vila Rica em 25 de maio de 1789: "que se havia de mudar a praça para o Rio das Mortes (S. João del Rei), por ser mais cômoda e farta de mantimentos; e que nesta vila haviam de pôr estudos como em Coimbra...". ${ }^{59}$

Com relação à questão da aplicação da ciência ao processo de industrialização do país libertado, opina Sérgio Buarque de Holanda que Maciel seria uma figura chave, em razão de sua formação e familiaridade com o nascente industrialismo inglês. Assim diz este historiador:

"A figura de Maciel está a reclamar investigações mais minuciosas. Ela nos interessa não só pela sua participação e seu desempenho na Inconfidência Mineira, mas também como representante dessa nova geração que na Europa recebia uma educação menos clássica, mais voltada para as ciências experimentais e que no Velho Mundo presenciara o impacto político produzido pela independência dos Estados Unidos. Pragmático por formação e tendências, como bem revela na discussão a propósito da libertação dos escravos, Maciel se inclinava mais para as ideias inglesas ou as instituições americanas do que para o racionalismo francês... é possível que sua ação tivesse maior amplitude do que a que os documentos da devassa deixam entrever". ${ }^{60}$

Apesar de Maciel negar todas as acusações e evitar demonstrar sua rara instrução, eximindo-se de qualquer tipo de participação na propaganda por um levante popular, consideraram-no os Senhores da Alçada um dos chefes e cabeças da sublevação. Nos acórdãos da Alçada, mostra-se, quanto a Maciel:

"que devendo repreender ao réu Tiradentes, pela primeira prática sediciosa que com ele teve, nesta cidade, e denunciá-lo ao Vice-Rei do Estado, pelo contrário foi quem aprovou a sublevação, e o animou para trabalhar em formar a rebelião, com práticas artificiosas, fazendo-os capacitar que, feito o levante, teriam prontamente socorros de potências estrangeiras, donde proximamente se recolhia, referindo-lhe conversações relativas a este fim, que dizia ter ouvido". ${ }^{61}$

Maciel foi condenado a morte, mas em 20 de abril de 1792, véspera da execução, teve essa pena comutada em degredo perpétuo pela Rainha D. Maria I, como muitos outros. Neste mesmo ano parte para o exílio na corveta "Nossa Senhora de Brota", com destino aos presídios angolanos. ${ }^{62}$

\section{MACIEL EM ANGOLA}

Em Luanda, os degredados foram levados à Fortaleza do Penedo. Maciel chegou com escorbuto, obstrução e ameaça de hidropisia (o que se repetiria anos depois), e foi medicado no hospital da fortaleza, sendo depois levado para Massangano. Em 1797, o novo Governador, Miguel Antonio de Melo, permitiu aos degredados morar em Luanda, e incumbiu Maciel de pesquisar os recursos minerais de Angola. ${ }^{63}$

Pouco se sabia das atividades de Maciel em Angola até a publicação do livro "Conspiradores que vieram deportados para os presídios de Angola, em 1792” pelo padre português Manuel Ruela Pombo (1888-1960), que publicou várias cartas dos degredados, como já foi observado acima. Nessas cartas temos informações das atividades de Maciel, do seu arrependimento, de suas pesquisas, de sua depressão e enfermidades. Essas cartas foram depois transcritas por Francisco Antonio Lopes no livro "Álvares Maciel no degredo de Angola”, publicado em 1958 pelo MEC. ${ }^{25}$
Através das cartas vamos encontrar um Maciel arrependido, que trata logo de se tornar útil para o governo português, aceitando as tarefas propostas pelo Governador de Angola, principalmente na construção de um forno siderúrgico nessa colônia.

Em carta datada de Luanda, em 4/11/1799, assim lhe escreve o Governador D. Miguel Antonio de Melo:

"Pelas ordens que Sua Majestade me mandou dirigir, e que eu li a vm tem vm entendido que à Mesma Senhora foi muito aceito o que vm propôs acerca do aproveitamento do ferro das minas deste Reino (Angola) e quão propenso se acha seu Augusto Espírito por efeito de sua inexaurível Clemência a afortunar a vm."

Na realidade, em 1799 a Rainha D. Maria I já não governava em virtude de sua doença mental, que a fizera ser substituída desde 1792 por seu filho o Príncipe Regente D. João. Continua o Governador na mesma carta:

"Encaminhar-se-á vm logo que esta receber à Província de Ilamba, e ao sítio denominado Trombeta, que fica na jurisdição do Golungo, acompanhado pelos dois pedreiros e um ferreiro, que com suas competentes ferramentas mandei aprontar, e no dito sítio, ou em outro vizinho e que mais próximo ficar às minas de ferro, e ao Rio Bengo, fará vm construir alguns fornos de capacidade conveniente para neles se fundir o dito metal, servindo-se para este efeito das pedras de cadilho que por grande fortuna há poucos dias aqui se acharam, resto das que para igual fim em outro tempo vieram, mas a que por pasmosa e nunca assaz lamentada fatalidade foi dado bem diverso e muito impróprio destino."

"Edificado o forno, ou fornos, que serão tantos quantos vm puder estabelecer, e fazer trabalhar, procurará vm aproveitar o mineral, fundindo-o pelo melhor modo que as circunstâncias permitirem, ensinando aos negros, que em semelhantes trabalhos se empregam, um método mais proveitoso que o que eles conhecem e usam para igual efeito, proporcionando as lições às suas capacidades, atraindo-os para o ensino, e para as tarefas para que vm necessitar de sua ajuda, com muita brandura, pagando-lhes com regularidade competentes jornais, segundo os estilos da terra, e comprando-lhes todo o ferro que eles em barra fundirem e a vm entregarem, por preço de vinte e cinco réis o arrátel". ${ }^{64}$

Diz ainda o Governador: "tenho determinado que o tesoureiro geral da junta da fazenda pague a vm em cada um mês quarenta mil réis, entregando-lhe logo três adiantados..." ${ }^{6}$ À mesma época, para fazer uma comparação, o químico brasileiro Vicente Seabra, professor em Coimbra, ganhava 350 mil réis por ano, ou cerca de 29 mil réis por mês, e o prestigiado José Bonifácio de Andrada e Silva, recebia da mesma universidade um salário de 800 mil réis por ano, ou quase 67 mil réis por mês. ${ }^{65}$

Na mesma data de 4/11/1799, o Governador D. Miguel Antonio de Melo escreve ao tenente do regimento de infantaria e regente do Golungo, Pedro Muzi de Barros: "José Álvares Maciel vai por ordem de Sua Majestade estabelecer na Província da Ilamba alguns fornos para aproveitar o ferro das minas que nela há e ensinar aos povos que aí habitam um método mais fácil do que aquele que conhecem e praticam para igual efeito. Também vai encarregado de comprar aos mesmos povos todo o ferro que eles fundirem em barra, e vm deve ficar na inteligência que este negócio é muito recomendado por Sua Majestade e que a vm toca auxiliar o dito Maciel por todos os modos lícitos para que consiga desempenhar a comissão de que o 
encarreguei. Ele fará a vm ver a instrução que lhe dirigi, e além dela cumpre ao Real Serviço ..." ${ }^{66}$

As cartas do Governador de Angola para o Ministro de Ultramar dão várias informações sobre, por exemplo, o salário de Maciel, de suas pesquisas mineralógicas em outras regiões, de seus relatórios sobre os trabalhos que vinha realizando, da marcha das operações para a fundição do ferro, dos recursos materiais e humanos necessários para a sua obra, etc. O Ministro corresponde, assinalando ao Governador da "interessante conta que a V.S. deu o hábil e digno Maciel". ${ }^{67}$

Maciel trabalha, persevera. Jovem, ainda mantém esperança do perdão português. No espírito do ex-conjurado encontra-se a saudade de seu país. Passa a ser dedicado, "derramando lágrimas de arrependimento por seus erros passados, e de gratidão pelos benefícios que sobre ele derrama Nosso Augusto Soberano". ${ }^{67,68}$

Em uma carta ao Governador encontramos um Maciel submisso e devotado:

"Poderá V. Excia. achar infinitos químicos mais hábeis do que eu, mas nenhum tão afeito aos rigores da África, nem tão interessado em fazer um serviço que pode levantar-me da profunda desgraça em que vivo. Portanto peço humildemente me desculpe algumas expressões, persuadido de que o ardente desejo que me devora é o de conseguir outra vez o inestimável bem. Bem da graça de Sua Majestade." ${ }^{68}$

Em 2/3/1800 Maciel escreve de Trombeta um longo relatório de seus trabalhos ao Governador, que principia com uma queixa: "as moléstias que tenho sofrido têm sido a causa de não ter dado a V. Excia. mais cedo conta do que tenho feito; agora, porém, que me acho melhor, o faço." Sobre as minas, assim diz ele: "a mina de Oeiras é muito rica, acha-se à superfície da terra e não contém nada de enxofre, nem zinco, apenas se descobre algum quartzo intermisto, e esse pouco; a de Calomba, pelo contrário, é uma mina limonosa muito pobre e sulfúrea, que se tira de minas de dez e quinze pés de fundo; a sua cor exterior é ferruginosa, a interior é preta, contendo alguns grãos luzentes, que naquele pedaço em que estes afundam representa o interior uma cor azul ferrete; é granulosa, muito frágil, e o ferro que produz é quebradiço a quente." Ele tem excelente conhecimento da técnica necessária: "tem-me pois ensinado a experiência que o ferro requer foles maiores para fazer conta, e estes que trouxe, estando consertados, só servem para experiências em pequeno ... o fundente, graças a Deus está descoberto, resta agora que se façam os foles, os quais devem ser ao menos de nove pés de comprido, e podem ser cobertos de couro, e um carpinteiro capaz para fazer os engenhos precisos para os tocar a mão ..."69

Numa carta-relatório que ele mandou escrever e assinou, datada de Luanda, em 31 de março de 1800, Maciel queixa-se de seu estado de saúde: "a 22 de março cheguei a esta capital com licença de V. Excia. para tratar da minha saúde que se acha bastantemente arruinada. $\mathrm{O}$ ardente desejo de ganhar a graça de Sua Alteza Real, e mesmo o reconhecimento pelos benefícios que estou recebendo, sem dúvida por intervenção de V. Excia., parece que dobraram as minhas faculdades, e apesar de excessivos trabalhos, sofrendo todos os dias cinco horas efetivas, e às vezes mais, na forja e no algaraviz, pude resistir até 17 do corrente, porém a obstrução que há muitos anos padeço aumentou-se por maneira que já não podia dormir deitado, sentindo os ameaços da hidropisia, que por causa da mesma obstrução tive em 1792. A este mal não pequeno se ajuntou algum escorbuto, mas depois que cheguei vou recebendo grandes melhoras, posto que não posso ainda por minha mão fazer esta pequena carta, em que dou conta a V. Excia. do estado em que deixei os meus trabalhos, e do que me parece se deve fazer." Segue-se uma minuciosa descrição técnica dos problemas encontrados na produção de ferro em Angola. Assim diz ele: "não basta ser fundidor em Espanha, para o ser também na França, ou em Angola, cada mina tem seu fundente próprio, o algaraviz para cada uma tem uma certa e determinada inclinação, coisas que só o estudo, a experiência, e observação de muitas pode fazer conhecer. Entre os mestres da Europa que não têm estudos são estas coisas do maior segredo, passando como patrimônio de pais a filhos. Estas dificuldades tenho eu vencido, que falta pois para fundir o ferro? Falta a fábrica com os engenhos competentes, faltam os homens e as coisas absolutamente necessárias para estes trabalhos, sem o quê todas as ordens e providências de V. Excia. se tornam inúteis e vãs, as minhas fadigas dobradamente excessivas, ficam infrutuosas, as rendas reais prejudicadas, e com estas faltas, ora de homens, ora de coisas, ou de uma e outra coisa como acabamos de experimentar, passa-se o tempo, nada aparece, e é natural ser eu por fim julgado um charlatão, ou ilusor."’70

A situação não mudou muito e Maciel retornou a Trombeta, de onde voltou a Luanda em virtude do agravamento de seu estado de saúde, mas sem abandonar seus trabalhos técnicos. Em 2/4/1801 ele manda escrever e assina uma carta ao Governador em que lista muitas de suas necessidades na fábrica de ferro: homens para suprir a crônica deficiência em mão de obra qualificada, equipamentos, e vários livros científicos, que precisavam vir da Europa. Na lista de livros necessários a sua atividade de metalurgista, separa aqueles que diz possuir e aqueles que gostaria de adquirir na Europa. Trata-se de livros científicos ou técnicos franceses ou em tradução francesa, com alguns erros de transcrição nos títulos ou nomes de autores. Ao final vem a observação: "N.B. Além destas obras necessitarei de algumas outras mais modernas, de que não posso dar notícia, porque há quatorze anos que nada sei da república literária". ${ }^{71}$

O Governador de Angola foi substituído por D. Fernando Antonio de Noronha. Este oficiou em 20/4/1803 ao novo Ministro do Ultramar, o Visconde de Anadia, apoiando tudo aquilo que Maciel pedia para poder continuar os trabalhos da fábrica de ferro, embora muito tempo depois da solicitação de Maciel. Em agosto o Ministro atendeu ao pedido do Governador e ordenou o envio dos materiais solicitados por Maciel. Todavia, em 15 de março de 1804 o Governador D. Fernando Antonio de Noronha escreve ao Ministro: "desgraçadamente, agora que eles devem chegar (os materiais pedidos), vem de morrer o Dr. Maciel, o único que existia neste Reino que fosse capaz de estar à testa do trabalho naquela mina." E mais além: “com a morte do Dr. Maciel não tenho com quem possa substituir a sua falta." ${ }^{2}$

\section{CONCLUSÃO}

Barbacena e Maciel protagonizaram vidas que um dia se cruzaram através da ciência, mas logo se separaram pelas vicissitudes da política. São exemplos do que poderia ter sido e não foi, de um profundo drama humano tendo como pano de fundo a ciência e suas aplicações. Por um lado, Maciel, jovem brilhante com uma carreira científica promissora à frente, teve sua vida destroçada e morreu prematuramente aos 43 anos, mergulhado em profunda depressão e várias doenças. Do outro, o aristocrata que começou a vida devotando-se à ciência, embora sem realizar muita coisa, mas foi levado pelo turbilhão da política. Embora viesse a ter longa carreira política após o regresso a Portugal, Barbacena é lembrado sobretudo pela repressão à Inconfidência Mineira.

Apesar do pouco que se conhece de pormenores a respeito das ideias e motivações, tanto de Barbacena como de Maciel, assim como de suas relações pessoais, pode-se inferir muita coisa a respeito de como esses indivíduos viam o papel da ciência e de suas aplicações no desenvolvimento da sociedade. Essas relações estão repletas de contradições, inerentes àquele tipo de sociedade, mas mesmo assim aquilo que se consegue entrever mostra um caleidoscópio rico e cheio de tessituras que merecem ser exploradas. 
A história da ciência no Brasil está repleta de descobertas e surpresas, e uma pesquisa forte e robusta poderá revelar-nos muitas coisas inesperadas que ainda jazem nos arquivos e bibliotecas.

Em 1936 o Presidente Getúlio Vargas mandou trazer para o Brasil os restos mortais dos Inconfidentes, que estavam dispersos em várias colônias portuguesas em África, incluindo-se os despojos de José Álvares Maciel. Em 21 de abril de 1942, sesquicentenário da execução de Tiradentes, eles foram trasladados para o Panteão dos Inconfidentes, no antigo prédio da Câmara e Cadeia de Vila Rica, transformado em Museu da Inconfidência. O museu se inaugurou em $1944 .^{73}$

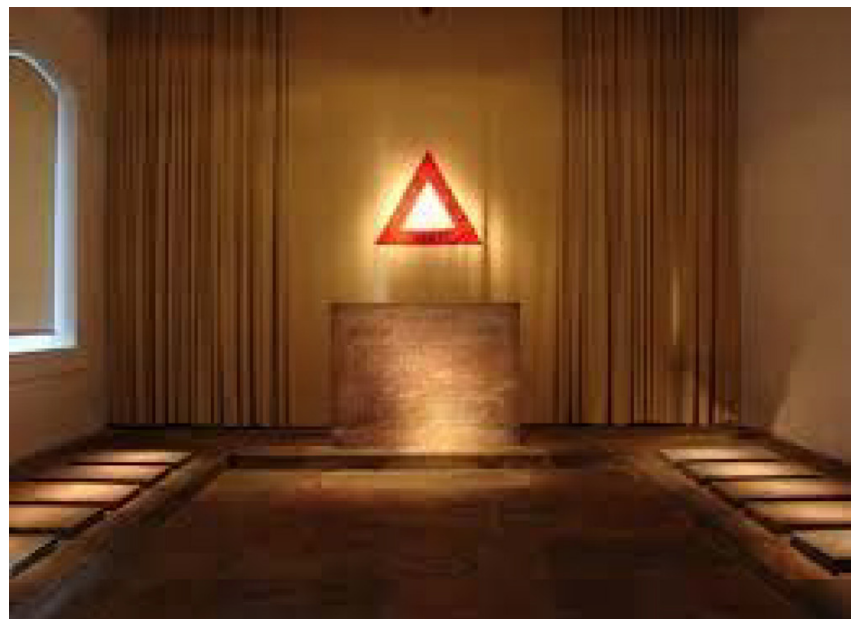

Figura 8. Panteão dos Inconfidentes, no Museu da Inconfidência, Ouro Preto. Aqui se encontram sepultados os restos de José Álvares Maciel e dos demais inconfidentes

\section{REFERÊNCIAS E NOTAS}

1. Boschi, C. C.; Exercícios de Pesquisa Histórica, Editora PUC Minas: Belo Horizonte, 2011, p. 107.

2. Ayres. C.; Para a História da Academia das Sciencias de Lisboa, Imprensa da Universidade: Coimbra, 1927, p. 48.

3. Os autores devem esta conclusão ao Prof. António Marinho Amorim da Costa, da Universidade de Coimbra, após buscas incessantes, ao qual agradecem.

4. Actas das Congregações da Faculdade de Filosofia (1772-1820), Universidade de Coimbra, 1978, Acta de 4-III-1776, p. 8.

5. Carvalho, J. A. S.; Memória Histórica da Faculdade de Philosophia, Imprensa da Universidade: Coimbra, 1872, p. 257.

6. Boschi, C. C., op. cit., pp. 101-210.

7. Brandão, T. J. F.; De Analogia Fluidum Electricum inter, et chymicorum Phlogisto, Dissertação de Mestrado 1367, 1778, pp. 1-12.

8. Carvalho, R.; Actividades Científicas em Portugal no Século XVIII, Universidade de Évora, 1996, 3-33 e 633-680.

9. Teague, M.; da Serra, J. C.; Documentos do seu Arquivo, Fundação Luso-Americana para o desenvolvimento, 1997, p. 44, apud Carvalho, A. S.; Mem. Acad. Ciências Lisboa, VI, 1948.

10. Teague, M.; op. cit., p. 65.

11. Ayres, C.; op. cit., pp. 50-94.

12. Ayres, C.; op. cit., pp. 52-53.

13. Iria, A. Em História e Desenvolvimento da Ciência em Portugal, Publicações do II Centenário da Academia das Ciências de Lisboa: Lisboa, 1986, pp. 1290-1291.

14. Almeida, T.; Recreação Filosofia ou Dialogo sobre a Filosofia Natural, para instrucção de pessoas curiosas, que não frequentarão as aulas, Regia Officina Typografica, tomos I a X, 1786-1800.

15. Ayres, C.; op. cit., p. 61.
16. Pinto, M. S.; Cecchini, M. A. G.; Malaquias, I. M.; Moreira-Nordemann, L. M.; Pita, J. R.; História, Ciência, Saúde-Manguinhos 2005, 12, 617.

17. Marques, A. J. M., Filgueiras, C. A. L.; Quim. Nova 2010, 33, 1612.

18. Filgueiras, C. A. L.; Origens da Química no Brasil, Editora da Unicamp: Campinas, 2015, pp. 116-122.

19. Iria, A.; op. cit., p. 1287.

20. Ayres, C.; op. cit., p. 65.

21. Instrucção para o Visconde de Barbacena Luiz Antonio Furtado de Mendonça, Governador e Capitão Geral da Capitania de Minas Geraes, Rev. Inst. Hist. Geogr. Bras. 1844, 6, 3.

22. Maxwell, K.; A Devassa da Devassa - A Inconfidência Mineira: BrasilPortugal - 1750-1808, 2 ed., Paz e Terra: Rio de Janeiro, 1978, p. 127.

23. Autos de Devassa da Inconfidência Mineira, Câmara dos Deputados/ Imprensa Oficial de Minas Gerais, $2^{\mathrm{a}}$ ed., Brasília/Belo Horizonte, vol. 2., p. 270.

24. Valadares, V. T.; Elites Mineiras Setecentistas - Conjugação de dois Mundos, Edições Colibri: Lisboa, 2004, pp. 500-501.

25. Lopes, F. A.; Álvares Maciel no degredo de Angola, Departamento de Imprensa Oficial - MEC: Rio de Janeiro, 1958, pp. 7-8.

26. Gazeta de Lisboa, 13/07/1784; $2^{\circ}$ suplemento, 17/07/1784.

27. Gazeta de Lisboa, 13/07/1784, $2^{\circ}$ suplemento, 01/01/1785.

28. Gazeta de Lisboa, 13/07/1784, $2^{\circ}$ suplemento, 16/07/1785.

29. Lopes, F. A.; op. cit., p. 8.

30. Fernandes Thomaz, M.; Malaquias, I. M.; Separata da Revista davUniversidade de Aveiro/Letras, 1987-88, 7.

31. Filgueiras, C. A. L.; Lavoisier - O Estabelecimento da Química Moderna, Odysseus; São Paulo, 2002, pp. 68-69.

32. Autos de Devassa, vol. 5, p. 332.

33. Autos de Devassa, vol. 9, p. 178-179.

34. Silva, J. N. S.; História da conjuração mineira, Imprensa Oficial: Rio de Janeiro, 1948, p. 46.

35. Silva, J. N. S.; op. cit., p. 47.

36. Autos de Devassa, vol 1, nota de Oliveira, T. J. B, p. 213.

37. Autos de Devassa, vol. 8, p. 28-35.

38. Autos de Devassa, vol. 2, p. 91.

39. Autos de Devassa, vol. 2, p. 270.

40. Autos de Devassa, vol. 8, p. 29.

41. Autos de Devassa, vol. 2, p. 281-282

42. Autos de Devassa, vol. 5, pp. 32-33.

43. Autos de Devassa., vol. 4, p. 48.

44. Iglesias, F.; Acervo da Revista do Arquivo Nacional, 1989, 4, n.1, 7.

45. Autos de Devassa, vol. 1, nota de Oliveira, T. J. B., p. 250.

46. Rouanet, S. P.; Em Tempo e História; Novaes, A., org.; Cia. das Letras: São Paulo, 1992, p. 335.

47. Autos de Devassa, vol. 4, p. 50.

48. Autos de Devassa, vol. 9, p. 40.

49. Autos de Devassa, vol. 8, p. 146. Autos, vol. 8, p. 14649.

50. Autos de Devassa, vol. 4, nota de Mathias, H. G., p. 169.

51. Autos de Devassa, vol. 8, nota de Oliveira, T. J. B., p. 162.

52. Souza, L. M.; Cláudio Manuel da Costa, Companhia das Letras: São Paulo, 2011, pp. 183-191.

53. Autos de Devassa, vol. 1, nota de Oliveira, T. J. B., p. 285

54. Autos de Devassa, vol. 1, p. 224.

55. Autos de Devassa, vol. 8, nota de Oliveira, T. J. B., p. 229

56. Lopes, F. A.; op. cit., pp. 41-42.

57. Lopes, F. A.; op. cit., p. 14.

58. Maxwell, K.; op. cit., pp. 151-152.

59. Autos de Devassa, vol.1, p. 124.

60. História geral da civilização brasileira, Holanda, S. B., org.; Difel: Rio de Janeiro, 1977, Livro I, v.2., p. 403.

61. Lopes, F. A.; op. cit., p.7.

62. Lopes, F. A.; op. cit., p. 3.

63. Autos de Devassa, vol.8, nota de Oliveira, T. J. B., pp. 371-372 
64. Lopes, F. A., op. cit., pp. 41-44. Nota: 1 arrátel, ou libra portuguesa, correspondia a 459 gramas.

65. Filgueiras, C. A. L.; Origens da Química no Brasil, Editora da Unicamp/ Editora da SBQ/Centro de Lógica, Epistemologia e História da Ciência, Campinas, 2015, p. 155.

66. Lopes, F. A.; op. cit., pp. 47-49.

67. Lopes, F. A.; op. cit., p. 22.
68. Lopes, F. A.; op. cit., p. 23.

69. Lopes, F. A.; op. cit., pp. 57-65.

70. Lopes, F. A.; op. cit., pp. 71-78.

71. Lopes, F. A.; op. cit., pp. 90-95.

72. Lopes, F. A.; op. cit., pp. 103-104.

73. O Museu da Inconfidência, Banco Safra, São Paulo, 1995. 